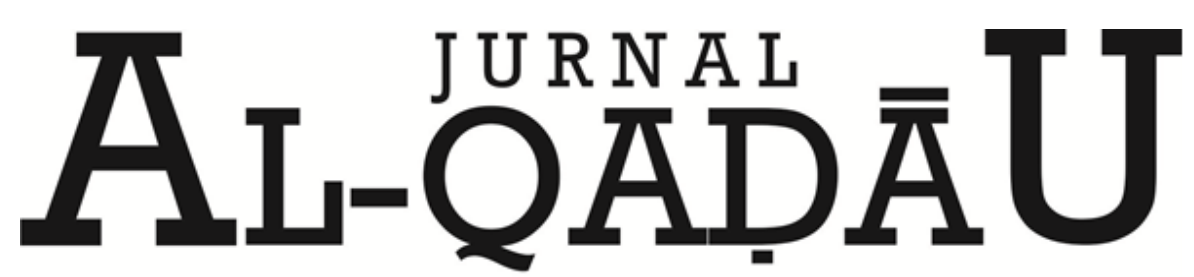

PERADILAN dan HUKUM KELUARGA ISLAM

\title{
Hukum Memilih Pemimpin Non Muslim
}

The Law of Choosing a non-Muslim leader

Sippah Chotban

Dosen Fakultas Syariah dan Hukum UIN Alauddin Makassar

Email: Sippahchotban@gmail.com

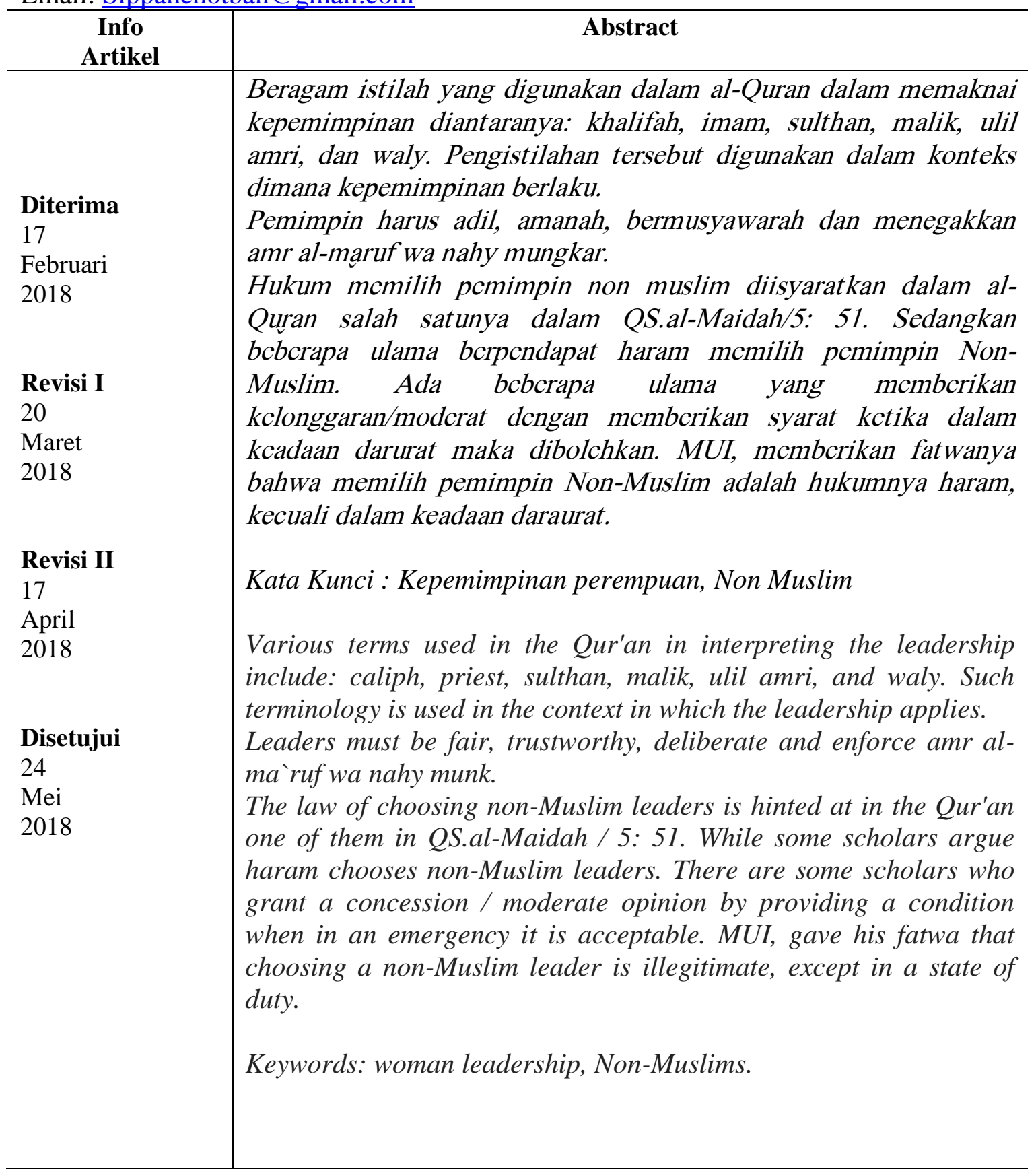




\section{A. PENDAHULUAN}

Islam sebagai agama wahyu, bagi setiap Muslim menjadi kerangka acuan paripurna untuk seluruh kehidupannya. Islam, dengan demikian merupakan sebuah agama penyatu yang lengkap (a relegion of Complete integration). ${ }^{1}$ Dalam konteksejarah, untuk pertama kalinya kita melihat ajaran mengenai pembangunan manusiamelalui integrasi yang utuh dengan dirinya sendiri, dengan masyarakat, denganalam semesta, dan bahwa integrasi ini berdasarkan atas adanya Allah SWT: TuhanYang Maha Esa dalam seluruh eksistensinya. ${ }^{2}$ Sehingga sejatinya persoalan politik dan Agama merupakan pembahasan yang saling terkait dan utuh ketika kita memperbincangkan Islam dan Politik.

Salah satu konsep ajaran yang ada dalam Islam adalah mengenai pemimpin dan memilih pemimpin. Islam memberikan kriteria yang harus dimiliki untuk menjadi pemimpin. Kriteria tersebut digariskan oleh Islam mengingat amanah menjadi seorang pemimpin sangatlah berat, di satu sisi. Di sisi lain, menjadi pemimpin juga merupakan amalan yang paling tinggi pahalanya, jika pemimpin tersebut sukses dalam memimpin.

Sehingga kepemimpinan adalah unsur yang tidak bisa dihindari dalam hidup ini.Sudah merupakan fitrah manusia untuk selalu membentuk sebuah komunitas.Dan dalam sebuah komunitas selalu dibutuhkan seorang pemimpin. Pemimpinadalah orang yang dijadikan rujukan dalam komunitas tersebut. Pemimpin adalahorang yang memberikan visi dan tujuan.

Sehingga demikian kebaradaan pemimpin sangat dibutuhkan dalam sebuah komunitas tertinggi yakni Negara. Dalam konteks Indonesia, memilih pemimpin diwujudkan dalam sebuah system demokrasi. Dalam hal pemiliihan kepala daerah tingkat kabupaten, dilaksanakan dalam kurung waktu satu periode yakni lima tahun diadakan pemilihan bupati. Pada tingkat di atas dari itu, yakni provinsi diadakan pemilihan gubernur dalam jangka waktu yang sama. Pada tingkat nasional diadakan pemilihan presiden untuk memimpin Negara, pemilihan di atas diperuntukkan untuk melaksanakan tugas dan fungsi pokok pada lembaga eksekutif. Selanjutnya juga diadakan pemilihan pada lembaga legislative juga diadakan pemilihan untuk memilih wakil rakyat yang akan diduduk dilembaga tersebut (DPR, DPRD, DPD).

Dalam konteks demokrasi, MUI memberikan fatwa terkait dengan haramnya golput, sehingga diharapkan pada setiap ummat Islam memberikan suara pada pemilihan tersebut. Pada konstitusi yang ada di Indonesia, kita diperhadapkan pada beragam calon pemimpin yang telah memiliki kualifikasi untuk mencalonkan dirinya pada pentas demokrasi. Latar belakang keagamaan yang beragamam pada calon tersebut, dan dalam konteks demokrasi memunculkan pertanyaan apakah hukumnya memilih pemimpin non muslim dalam syariah Islam.

\section{B. METODE PENELITIAN}

Jenis penelitian ini merupakan library research (penelitian pustaka) yakni menelah berbagai referensi yang relevan dengan masalah yang diteliti, menggunakan pendekatan yuridis dan historis.

${ }^{1}$ Hakim Mohammad Said, Moralitas politik: Konsep mengenai Negara, dalam A.E. Proyono (ed), Islam Pilihan Peradaban, (Cet. I; Yogyakarta: Shalahuddin Press, 1884), h. 72

${ }^{2}$ Hakim Mohammad Said, Moralitas politik: Konsep mengenai Negara, dalam A.E. Proyono (ed), Islam Pilihan Peradaban, h. 72 
Metode pengumpulan bersumber dari : 1. Data Primer, yaitu data yang diperoleh diperoleh dari berbagai literatur yang terkait dengan permasalahan., 2. Data Sekunder, yaitu data yang diperoleh dari berbagai literatur, peraturan perundang-undangan, pendapat para ahli hukum, dokumen serta tulisan lain yang terkait materi yang dibahas sebagai penunjang.

Data yang berhasil diperoleh atau yang berhasil dikumpulkan selama proses penelitian baik itu data primer dan sekunder dianalisis secara kualitatif kemudian disajikan secara deskriptif yaitu menguraikan, menggambarkan, dan menjelaskan sesuai dengan permasalahan yang erat kaitannya dengan penelitian ini

\section{PEMBAHASAN}

\section{KONSEP KEPEMIMPINAN DALAM ISLAM}

Kebutuhan dan kehadiran seorang pemimpin adalah wajib. Hal ini karena, pemimpin merupakan hal yang sangat final dan fundamental. Ia menempati bangunan yang tertinggi dalam komunitas suatu masyarakat, ia memiliki peranan yang strategis dalam pengaturan pola (manhaj) dan gerakan (harakah). Kecakapannya dalam memimpin akan mengarahkan ummatnya kepada tujuan yang ingin dicapai, yakni kejayaan dan kesejahteraan ummat dengan iringan ridho Allah swt. Terminologi kepemimpinan dalam Islam merujuk pada kata khalîfah, amîr, uli al-amri, imâm, sultân dan mulk.

Istilah pertama, Khalifah. Kata Khalifah disebut sebanyak 127 kali dalam alQur'an, yang maknanya berkisar diantara kata kerja: menggantikan, meninggalkanatau kata benda pengganti atau pewaris, tetapi ada juga yang artinya telah "menyimpang" seperti berselisih, menyalahi janji, atau beraneka ragam. ${ }^{3}$ Sedangkan dari perkataan khalf yang artinya suksesi, pergantian atau generasi penerus, wakil, pengganti, penguasayang terulang sebanyak 22 kali dalam Al-Qur'an - lahir kata khilafah. Kata ini menurut keterangan Ensiklopedi Islam, adalah istilah yang muncul dalam sejarah pemerintahan Islam sebagai institusi politik Islam, yang bersinonim dengan kata imamah yang berarti kepemimpinan. ${ }^{4}$

Istilah kedua, Imam. Dalam al-Qur'an, kata imam terulang sebanyak 7 kali dan kata aimmah terulang 5 kali. Kata imam dalam Al-Qur'an mempunyai beberapa arti yaitu, nabi, pedoman, kitab/buku/teks, jalan lurus, dan pemimpin. ${ }^{5}$ Konsep imam dari beberapa ayat (QS. al-Furqan:74, al-Anbiya: 73, al-Baqarah: 124, dan al-Qashash: 4) menunjukkan suami sebagai pemimpin rumah tangga dan juga nabi Ibrahim sebagai pemimpin umatnya. Konsep imam di sini, mempunyai syarat memerintahkan kepada kebajikan sekaligus melaksanakannya. Dan juga aspek menolong yang lemah sebagaimana yang diajarkan Allah, juga dianjurkan.

Istilah Ketiga, Ulu al-Amri. Istilah Ulu al-Amri oleh ahli Al-Qur'an, Nazwar Syamsu, diterjemahkan sebagai functionaries, orang yang mengemban tugas, atau diserahi menjalankan fungsi tertentu dalam suatu organisasi. ${ }^{6} \mathrm{Hal}$ yang menarik

${ }^{3}$ M. Dawam Raharjo, Ensiklopedi Al-Qur'an: Tafsir Sosial Berdasarkan Konsep-konsep Kunci, (Cet. II; Jakarta: Paramadina, 2002), h. 349.

${ }^{4}$ M. Dawam Raharjo, Ensiklopedi Al-Qur'an: Tafsir Sosial Berdasarkan Konsep-konsep Kunci, h. 357 .

${ }^{5}$ Said Agil Husin Al-Munawar, Al-Qur'an Membangun Tradisi Kesalehan Hakiki, (Cet. I; Jakarta: Ciputat Press, 2002), h. 197-199. h. 466 .

${ }^{6}$ M. Dawam Raharjo, Ensiklopedi Al-Qur'an: Tafsir Sosial Berdasarkan Konsep-konsep Kunci, 
memahami konsep uli al-Amri ini adalah keragaman pengertian yang terkandung dalam kata amr. Istilah yang mempunyai akar kata yang sama dengan amr yang berinduk kepada kata a-m-r, dalam Al-Qur'an berulang sebanyak 257 kali. Sedang kata amr sendiri disebut sebanyak 176 kali dengan berbagai arti, menurut konteks ayatnya. ${ }^{7}$ Kata amr bisa diterjemahkan dengan perintah (sebagai perintah Tuhan), urusan (manusia atau Tuhan), perkara, sesuatu, keputusan (oleh Tuhan atau manusia), kepastian (yang ditentukan oleh Tuhan), bahkan juga bisa diartikan sebagaia tugas, misi, kewajiban dan kepemimpinan. ${ }^{8}$

Sulthan, akar kata ini adalah sin-lam-tha dengan makna pokok yakni "kekuataan dan paksaan" kata sulthan dalam al-Qur'an dipergunakan sebagai kekuasaan, kekutaan memaksa, alasan, bukti dan ilmu pengetahuan. ${ }^{9}$ Penggunaan kata sultan untuk makna pemimpin tersebut berkonotasi sosiologis, karena ia berkenaan kemampuan untuk mengatasi orang lain.Sehingga jelaslah bahwa kata tersebut lebih relevan dengan konsep kemampuan dari pada konsep kewenangan (otoritas). ${ }^{10}$

Sedangkan, kata mulk. Mengandung makna pokok "keabsahan dan kemampuan" sehingga konsep kepemimpinan dalam makna kata ini dengan sifat umum dan berdimensi pemilikan. Bertolak dari defenisi diatas bahwa kata maliktidak hanya bermakna kekuasaan tetapi juga bermakna kepemilikan. Sehingga jika dikaitkan dengan kekuasaan politik, berimplikasi sebagai pemimpin sebagai pemberian Tuhan kepadanya. ${ }^{11}$ Sehingga kata mulk ini sekiranya tidak relevan dipergunakan dalam konteks kepemimpinan politik.

Disamping itu, al Quran juga menyebutkan kata qawwāmah sebagai makna pemimpin, kata tersebut menunjukkan rasa tanggung jawab penuh laki-laki terhadap wanita. Hal inilah yang menjadikan laki-laki didaulat menjadi pemimpin bagi wanita. Qawwāmah memiliki makna selalu bekerja sehingga mengisyaratkan bahwa di dalam perkerjaan tersebut terdapat kesusahan. ${ }^{12}$

Selain itu al-Quran juga menggunakan kata Wilayahyang juga dapat bermakna memerintah, menguasai, menyayangi dan menolong (pembahasan ini akan dibahas khusus pada sub bab selanjutnya).

Kemudian dalam Al-Qur'an menyebutkan prinsip-prinsip kepemimpinan antara lain: amanah, adil, syura (musyawarah), dan amr bi al-ma'ruf wa nahy 'an al-munkar.

\section{Amanah}

Kamus kontemporer (al-'Ashr), kata amanah diartikan dengan kejujuran, kepercayaan (hal dapat dipercaya). ${ }^{13}$ Amanah ini merupakan salah satu sifat wajib bagi

${ }^{7}$ M. Dawam Raharjo, Ensiklopedi Al-Qur'an: Tafsir Sosial Berdasarkan Konsep-konsep Kunci,

${ }^{8}$ M. Dawam Raharjo, Ensiklopedi Al-Qur'an: Tafsir Sosial Berdasarkan Konsep-konsep Kunci, h. 466 .

${ }^{9}$ Muhammad Ibrahim Ismail, Mu`jam al-Alfazh wa al-A `am al-Qur`aniyat (al-Qahirat: Dar alFikr al-Arabi, t.th), h. 274.

${ }^{10}$ Abdul Muin Salim, Fiqh Slyasah: Konsepsi Kekuasaan Politik dalam al-Qur`an (Cet. III; Jakarta: Raja Grafindo Persada, 2002), h. 159-160.

${ }^{11}$ Abdul Muin Salim, Fiqh Siyasah: Konsepsi Kekuasaan Politik dalam al-Qur`an, h. 160-162.

${ }^{12}$ Muhammad Mutawally al-Sha'rāwī, Tafsìr al-Sha'rāwī, Vol 4 ( Kairo : Matāāi' Akhbār alYaum, 1997), h. 2193.

${ }^{13}$ Atabik Ali \& Ahmad Zuhdi Mudlor, Kamus Kontemporer Arab Indonesia, (Yogyakarta: Yayasan Ali Maksum, tt), h. 215. 
Rasul. Ada sebuah ungkapan "kekuasan adalah amanah, karena itu harus dilaksanakan dengan penuh amanah".amanah. Amanah dalam hal ini adalah sikap penuh pertanggungjawaban, jujur dan memegang teguh prinsip. Amanah dalam arti ini sebagai prinsip atau nilai. ${ }^{14}$ Mengenai amanah ini Allah swt berfirman dalam QS. Ahzab/33:72.

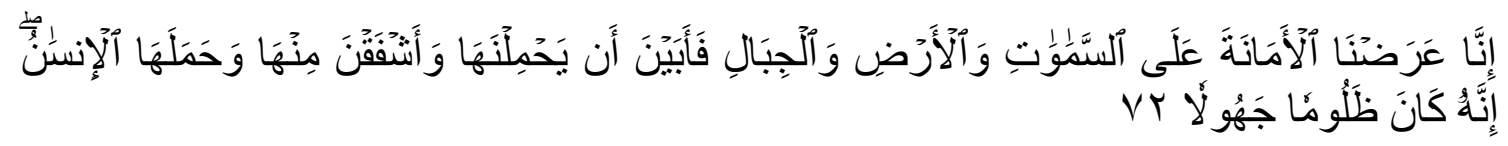

Terjemahnya:

Sesungguhnya Kami telah mengemukakan amanat kepada langit, bumi dan gunung-gunung, maka semuanya enggan untuk memikul amanat itu dan mereka khawatir akan mengkhianatinya, dan dipikullah amanat itu oleh manusia. Sesungguhnya manusia itu amat zalim dan amat bodoh. ${ }^{15}$

Dalam menjalankan amanah kepemimpinan, oleh sebab itu seorang pemimpin harus cerdas (fathanah). Agar pemimpin dapat menjalankan amanah, maka pemimpin harus didukung dengan bekal ilmu pengetahuan dan hidayah dari Allah. Pengajarannya bisa lewat hidayah yang merupakan anugerah dari Allah, juga bisa melalui ilmu pengetahuan.

\section{Adil}

Dalam bahasa kontemporer, keadilan di atas lebih dikenal dengan istilah supremasi hukum. Pemimpin yang baik dan bagus adalah pemimpin yang dapat menegakkan hukum kepada siapapun walaupun itu adalah anaknya sendiri. Namun alangkah menyedihkan ketika kita melihat realitas bangsa kita sebagai bangsa yang mayoritas beragama Islam. Kita melihat hukum dipermainkan sedemikian rupa, Hukum bahkan berharga sangat mahal. ${ }^{16}$ Allah swt memerintahkan untuk berbuat adil bagi pemimpin dalam QS ash-Shad/38: 26.

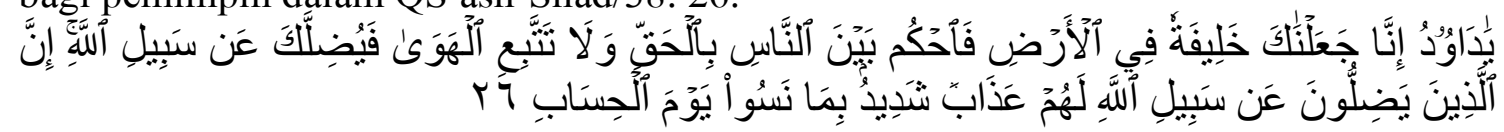

Terjemahnya:

Hai Daud, sesungguhnya Kami menjadikan kamu khalifah (penguasa) di muka bumi, maka berilah keputusan (perkara) di antara manusia dengan adil dan janganlah kamu mengikuti hawa nafsu, karena ia akan menyesatkan kamu dari jalan Allah. Sesungguhnya orang-orang yang sesat darin jalan Allah akan mendapat azab yang berat, karena mereka melupakan hari perhitungan. ${ }^{17}$

3. Syura (Musyawarah)

Al-Qur'an dengan jelas menyatakan bahwa seseorang yang menyebut dirinya pemimpin wajib melakukan musyawarah dengan orang yang berpengetahuan atau orang yang berpandangan baik. ${ }^{18}$ Sebagaimana Firman Allah SWT surat Asy Syura' $/ 42: 38$

\footnotetext{
${ }^{14}$ Said Agil Husin Al-Munawar, Al-Qur'an Membangun Tradisi Kesalehan Hakiki, , h. 200.

${ }^{15}$ Kementerian Agama RI, al-Qur`an dan Terjemahnya (Cet. III; Jakarta: Syamil Qur`an, 2014), h. 427.

${ }^{16}$ Atabik Ali \& Ahmad Zuhdi Mudlor, Kamus Kontemporer Arab Indonesia, h. 190.

${ }^{17}$ Kementerian Agama RI, al-Qur`an dan Terjemahnya, h. 454.

${ }^{18}$ Veithzal Rivai, Kiat Memimpin Abad ke-21, (Cet. I; Jakarta: Raja Grafindo. 2004), h. 7
} 
Sippah Chotban

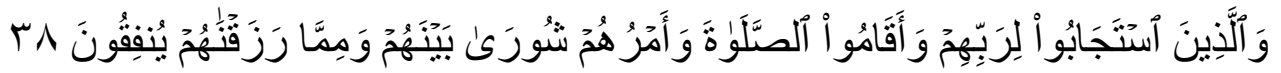

Terjemahnya:

Dan (bagi) orang-orang yang menerima (mematuhi) seruan Tuhannya dan mendirikan shalat, sedang urusan mereka (diputuskan) dengan musyawarat antara mereka; dan mereka menafkahkan sebagian dari rezeki yang Kami berikan kepada mereka. ${ }^{19}$

\section{4. amr bi al-ma'ruf wa nahy 'an al-munkar}

Prinsip keempat, amr ma'ruf nahi munkar, yaitu "suruhan untuk berbuat baik serta mencegah dari perbuatan jahat." Istilah itu diperlakukan dalam satu kesatuan istilah, dan satu kesatuan arti pula, seolah-olah keduanya tidak dapat dipisahkan. ${ }^{20}$ Ma'ruf diartikan sebagai segala perbuatan yang mendekatkan diri kepada Allah; sedangkan munkar ialah segala perbuatan yang menjauhkan dari pada-Nya. Dengan demikian dapat dipahami bahwa prinsip kepemimpinan amr ma'ruf dan nahi munkar sangat ditekankan oleh Allah karena dari prinsip ini akan melahirkan hal-hal yang akan membawa kebaikan pada suatu kepemimpinan. Sebagai dalam QS. al-Hajj/22 : 41 .

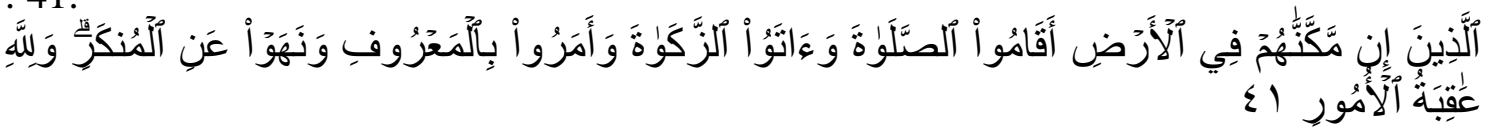

Terjemahnya:

(yaitu) orang-orang yang jika Kami teguhkan kedudukan mereka di muka bumi niscaya mereka mendirikan sembahyang, menunaikan zakat, menyuruh berbuat máruf dan mencegah dari perbuatan yang mungkar; dan kepada Allah-lah kembali segala urusan. ${ }^{21}$

Selanjutnya Al-Mawardi dalam Kitabnya, yang memberi perhatian pada sistem tata negara memberikan syarat-syarat yang harus dimiliki pemimpin (imamah/khalifah), yakni antara lain: 1). Adil dalam bertindak. 2). Memiliki keluasan ilmu dan mampu berijtihad. 3). Sehat jasmani, yang dengannya ia dapat melakukan tindakan-tindakan dalam kepemimpinan. 4). Sehat organ tubuh (tidak cacat). 5). Pengalaman kepemimpinan. 6). Memiliki keberanian untuk melindungi negara dan melawan musuh. ${ }^{22}$ Selanjutnya menurut al-Mawardi, seperti dikutip Bakir Ihsan bahwa kepemimpinan politik yang kuat harus didasarkan pada aspek spiritual. Ia tidak bisa mengandalkan aspek akalsemata. Oleh karena itu setiap persoalan yang menyangkut kepemimpinan dan kekuasaan, selain berdasarkan pada petunjuk-petunjuk rasional, juga membutuhkan petunjuk ajaran agama. ${ }^{23} \mathrm{Hal}$ ini menunjukkan bahwa seorang pemimpin selain ia harus cakap dan pandai, ia juga harus berpegang pada nilai-nilai agama.

\footnotetext{
${ }^{19}$ Kementerian Agama RI, al-Qur`an dan Terjemahnya, h. 487.

${ }^{20}$ M. Dawam Raharjo, Ensiklopedi Al-Qur'an: Tafsir Sosial Berdasarkan Konsep-konsep Kunci, h. 219

${ }^{21}$ Kementerian Agama RI, al-Qur`an dan Terjemahnya, h. 337

${ }^{22}$ Al-Mawardi, al-Ahkam al-Sulthaniyyah: Hukum-Hukum Penyelenggaraan Negara dalam Syariat Islam, pent. Fadli Bahri, (Jakarta: Darul Falah, 2007), h. 6

${ }^{23}$ A. Bakir Ihsan, "Referensi Pemikiran Politik NU", dalam Jurnal Refleksi: Jurnal Ilmu-ilmu Ushuluddin, vol. XI, No 2, 2009, h. 170
} 


\section{HUKUM MEMILIH PEMIMPIN NON-MUSLIM DALAM ISLAM}

\section{Al-Qur`an}

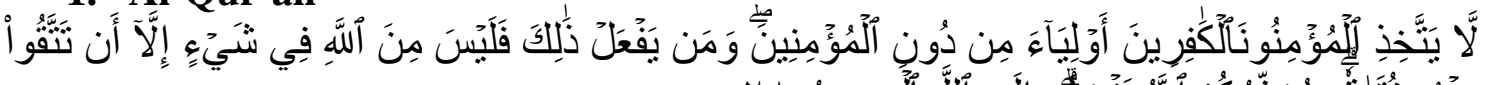

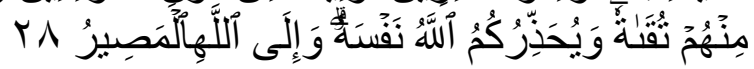

Terjemahnya:

Janganlah orang-orang mukmin mengambil orang-orang kafir menjadi pemimpin dengan meninggalkan orang-orang mukmin. Barang siapa berbuat demikian, niscaya lepaslah ia dari pertolongan Allah, kecuali karena (siasat) memelihara diri dari sesuatu yang ditakuti dari mereka. Dan Allah memperingatkan kamu terhadap diri (siksa)-Nya. Dan hanya kepada Allah kembali(mu). ${ }^{24}$

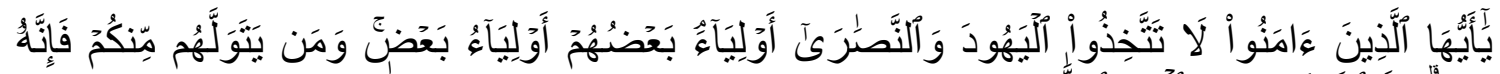

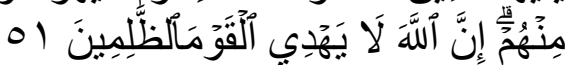

Terjemahan:

Hai orang-orang yang beriman, janganlah kamu mengambil orang-orang Yahudi dan Nasrani menjadi pemimpin-pemimpin(mu); sebahagian mereka adalah pemimpin bagi sebahagian yang lain. Barangsiapa diantara kamu mengambil mereka menjadi pemimpin, maka sesungguhnya orang itu termasuk golongan mereka. Sesungguhnya Allah tidak memberi petunjuk kepada orang-orang yang zalim. $^{25}$

Selain tiga ayat di atas, masih banyak lagi ayat lainnya yang bernada penolakan pemimpin non-muslim, yaitu: al-Maidah: 57, al-Mumtahanah: 1, al-Mujadalah: 22, alNisâ: 141 dan 144, al-Anfâl: 73, al-Taubah: 71, al-Taubah: 8, Ali Imrân: 100 dan 118.Ayat-ayat ini yang mendasari beberapa ulama klasik hingga kontemporer melakukan penolakan pemimpin non muslim. Diantara penafsir dan ulama yang tegas menolak pemimpin non muslim adalah: al-Jashâsh, al-Zamakhsyarî, ${ }^{26}$ al-Alûsi, alArabî, Ibn Kathîr, ${ }^{27}$ al-Qurtubî, Wahbah Zuhaili, al-Thaba'thaba'̂̂, al-Mawardî, Abdu al-Wahab Khalâf, Taqîyu al-Dîn Nabhanî dan lain-lain. ${ }^{28}$

Kata أَوْلِيَاءَ(auliya') adalah bentuk plural dari ولي (waliy) yang bertaut erat dengan konsep wala' atau muwalah yang mengandung dua arti: pertama, pertemanan dan aliansi; kedua proteksi atau patronase (dalam kerangka relasi patron-klien). Dalam

${ }^{24}$ Kementerian Agama RI, al-Qur`an dan Terjemahnya, h.53.

${ }^{25}$ Kementerian Agama RI, al-Qur`an dan Terjemahnya, h. 117.

${ }^{26}$ Lihat penafsiran al-Zamakhsyari dalam menafsirkan surah al-Maidah ayat 51 dalam alKasysyâf 'An Haqâiqi Ghamâmi al-Tanzîl wa 'Uyûn al-Aqawîl fî̀ Wujûh al-Ta'wîl, vol. 2 (Riyadh: Maktabah 'Abikan, 1998), h. 249

${ }^{27}$ Lihat penafsiran Ibn Kathîr dalam menafsirkan surah Ali Imran ayat 28, 100 dan 118 yang menjelaskan larangan melilih pemimpin yang kafir dan menjalin hubungan dengan mereka. Abu Fidâ alHâfid ibn Kathîr, Tafsîr al-Qur'ân al- 'Azîm, Vol 1 (Beirut: Dâr al-Fikr, 2011), h. 325, 351 dan 359.

${ }^{28}$ Mujar Ibn Syarif, "Memilih Presiden Non Muslim di Negara Muslim dalam Perspektif Hukum Islam”, dalam Jurnal Konstitusi PPK Fakultas Syariah IAIN Antasari, Vol II nomer 1 Tahun 2009, h. 9293. 
Sippah Chotban

kamus lisanul arab, kata waliy berarti shiddiq(teman) dan an-nashir(penolong). ${ }^{29}$ Kemudian dalam terjemahan the holy qur'an yang ditulis oleh Abdullah yusuf Ali, kata auliya diartikan friends(teman). ${ }^{30}$

Menurut riwayat dari Ibnu jarir Ayat ini diturunkan ketika Al-hajjaj bin amr, ka'ab bin al-asyraf, ibnu abil haqiq dan qais bin zaid(golongan yahudi) tinggal berbaur bersama orang-orang anshar untuk mengganggu keislaman mereka dan menjadikan mereka murtad. Maka Rifa'ah ibnul mundzir, Abdullah bin Zubair, dan sa'id bin Hatsamah berkata kepada mereka : Jauhilah orang yahudi itu dan janganlah tinggal bersama mereka agar mereka tidak membuat kalian keluar dari agama kalian. Kemudian turunlah ayat ini. ${ }^{31}$ Ayat ini diturunkan kepada sekelompok orang Islam pada waktu itu untuk waspada ketika berelasi dengan orang yahudi atau kafir, ini dikarenakan orang kafir pada waktu itu sangat memusuhi Islam. Sehingga dikhawatirkan bergaul dengan mereka akan menjadikan orang-orang muslim murtad.

Menurut Fakhruddīn ar-Rāzī dalam tafsirnya, menjadikan orang-orang kafir sebagai 'sekutu' (muwālāt al-kāfir) mengandung tiga pengertian. Pertama, meridhoi kekufuranmereka, dan ini jelas dilarang, karena merestui kekufuran itu kufur (ar-rị̣ā bil kufrikufrun). Kedua, bergaul dengan mereka secara baik (al-mu'āsyarah al-jamīlah) di dunia sesuai kenyataan, dan ini tidak dilarang. Ketiga, berpihak atau condong kepada mereka (ar-rukūn ilayhim), mengulurkan bantuan (al-ma ūnah), mendukung mereka (almuzāăharah), dan membela kepentingan mereka (an-nușrah), dan ini tindakan pun dilarang (manhiyyun 'anhu), kendati tidak membuat pelakunya kafir. ${ }^{32}$

Kata awliyā' atau wali-wali itu berarti dua hal: yaitu, memberikan dukungan dan pembelaan jika lafaznya dibaca walāyah (dengan fathah), dan menyerahkan mandat atau memberi kekuasaan jika lafaznya dibaca wilāyah (dengan kasrah) ${ }^{33}$ Maka secara politis dan geografis, muwālatul kuffār tidak hanya berarti menjalin kerjasama atau beraliansi, tetapi juga menyerahkan "wilayah" kita kepada orang kafir.

\section{Pendapat Ulama Larangan Memilih Pemimpin Non Muslim}

Mengacu kepada ayat-ayat tersebut, al-Jașạās misalnya memberikan catatan bahwa dalam ayat ini (QS. 'Ali Imran: 28) dan ayat-ayat lain yang isinya senada dengannya ada petunjuk bahwa dalam hal apapun orang kafir tak boleh berkuasa atas (umat) Islam. ${ }^{34}$ Atas dasar keyakinan serupa itu, al-Jashshash tidak hanya tak membolehkan umat Islam mengangkat non-Muslim sebagai kepala negara, tapi juga tak boleh melibatkan non-Muslim dalam segala urusan umat Islam, sekalipun ada

\footnotetext{
${ }^{29}$ Muhammad ibn Manzhur, Lisanul I’rab, Juz 8(Beirut: dar al-Shadir, 1968), : لسان العرب محمد بن كرم بن منظور الأفريقي المصريدار صادر - بيروت

${ }^{30}$ Yusuf Ali, Abdullah, The Holy Quran, Text, Translation and Comentary (Lahore: Muhammad Ashraf, 1938), h.224.

${ }^{31}$ Wahbah az-Zhuhaili, Tafsir al-Manar Fi al-Aqidah wa Syar`iyah Wa al-Manhaj juz 3(Damaskus: Dar al-Fikr al-Ma`asyir, t.th): : التفسير المنير في العقيدة والثريعة والمنهج و هبة بن مصطفى الزحيلي الناشر دار الفكر المعاصر - دمشق h. 198. h.1603-1604

${ }^{32}$ Fakhruddīn ar-Rāzī,Tafsīr al-Kabīr, juz 7, jilid 3, (Cet. I; Dār al-Fikr Beirut 1425/2005), h. 885 .

${ }^{33}$ Ar-Rāghib al-Ișfahāni, Mufradāt Alfāza al-Qur'ān (Cet. I; Dār al-Qalam Damaskus, 1412/1992),

${ }^{34}$ Abu Bakar Ahmad Ibn Ali ar-Razi al-Jașșāṣ, Aḥkām al-Qur'ān (Cet. II; Kairo: Maktabah wa Mathba'ah Abd ar-Rahman Muhammad, t.t), h. 290.
} 
pertalian darah dengannya. Karena itu, seorang pria non-Muslim, menurut dia, tidak punya hak untuk mengurus prosesi pernikahan putra kandungnya yang Muslim karena alasan beda agama. ${ }^{35}$

Senada dengan al-Jashshash Ibnu 'Arabi menyatakan, ayat-ayat tersebut berisi ketentuan umum bahwa seorang Mu'min tidak boleh mengambil orang kafir sebagai pemimpinnya, sekutunya untuk melawan musuh, menyerahkannya suatu amanat, dan atau menjadikannya sebagai teman kepercayaan. ${ }^{36}$

Sejalan dengan pendapat Ibnu 'Arabi di atas, Ibn Katsir menyatakan, ayat-ayat tersebut merupakan larangan Allah kepada hamba-Nya yang beriman, berteman akrab dengan orang-orang kafir dan atau menjadikannya sebagai pemimpinnya, dengan meninggalkan orang-orang yang beriman. Sebab jelas hal ini merupakan perwujudan cinta kasih umat Islam terhadap non-Muslim. Siapa saja di antara umat Islam yang membangkang terhadap Allah dengan mengasihi musuh-musuh-Nya dan memusuhi para kekasih-Nya, tegas Ibnu Katsir, akan mendapatkan siksa-Nya. ${ }^{37}$ Kecuali bila di beberapa negara dan dalam beberapa kesempatan tertentu seorang (Muslim) takut terhadap kejahatan orang-orang Kafir, maka ia diberi dispensasi untuk ber-taqiyyah di hadapan mereka secara zahirnya saja, tidak dalam batin dan niatnya.

Ibnu Katsir mendukung pendapatnya dengan firman Allah dalam (QS. alNahll/16: 106): yang didukung oleh hadis yang diriwayat Imam Bukhari yang bersumber dari Abu Darda, yangberbunyi sebagai berikut, Sesungguhnya kami (sering) tersenyum $d i$ hadapan beberapa kaum, sedangkan (sebenarnya) hati kami mengutukinya. ${ }^{38}$

Ibnu Katsir menyetujui larangan memilih non-Muslim sebagai pemimpin umat Islam, disamping didasarkan pada beberapa ayat Al-Qur'an, sebagaimana disinggung sebelum ini, juga didasarkan pada hadis riwayat Imam an-Nasa'i yang bersumber dari mujahid, yang berbunyi:Janganlah kamu mencari penerangan dari api orang-orang Musyrik. $^{39}$

Kemestian menolak presiden non-Muslim menurut Wahbah az-Zuhaili, juga didasarkan pada hadis marfu' yang ditakhrij oleh at-Turmudzi, al-Hakim, dan atTTabrani, yang berbunyi: Allah swt. berfirman: Demi kekuasaan-Ku tidak akan mendapat rahmat-Ku seseorang yang tidak mencintai kekasih-Ku dan tidak memusuhi musuh-musuh-Ku. ${ }^{40}$

Az-Zamakhsyari dan al-Baiḍāwi menambahkan satu hadis lagi, yakni hadis yang diriwayatkan oleh ahl al-Sunan (at-Turmudzi, an-Nasa'i, Abu Dawud, dan Ibn Majah) yang berbunyi: Aku lepas hubungan dengan setiap Muslim yang berada di bawah kekuasaan orang-orang Musyrik. Nabi ditanya, ya, Rasul Allah, mengapa (demikian)? Nabi bersabda: (Sebab) api (kekuatan) keduanya sulit teridentifikasi. ${ }^{41}$

\footnotetext{
${ }^{35}$ Abu Bakar Ahmad Ibn Ali ar-Razi al-Jașșāṣ, Aḥkām al-Qur’ān, h. 290.

${ }^{36}$ Abu Bakr Muhammad ibn Abdillah Ibn Arabi, Ahkām al-Qur'ān (Cet. II; Beirut: Dar alKutub al-'Ilmiyyah, 1988), h. 138-139.

${ }^{37}$ Ibnu Kas̄ir ad-Dimasyqi, Tafsìr al-Qur'ān al-Azim (Cet. I; Beirut: Dar al-Fikr, 1992), h. 439.

${ }^{38}$ Ibnu Kasīir ad-Dimasyqi, Tafsir al-Qur'ān al-Aẓim, h. 439.

${ }^{39}$ Ibnu Kasīir ad-Dimasyqi, Tafsir al-Qur'ān al-Ažìm, h. 439.

${ }^{40}$ Wahbah az-Zuhaili, at-Tafsir al-Munir fi al-'Aqïdah wa asy-Syarī'ah wa al-Manhaj, h. 59.

${ }^{41}$ Muhammad 'Abduh dan Rasyīd Riḍ̄a, Tafsir al-Qur'an al-Hakim (Tafsir al-Manār), (Cet. VI; Beirut : Dār al-Mā'rifah, t.t), h. 429.
} 
Dilarangnya umat Islam mengangkat non-Muslim sebagai pemimpinnya, menurut al-Zamakhsyari adalah logis mengingat orang-orang Kafir adalah musuh umat Islam, dan pada prinsipnya memang tak akan pernah mungkin bagi seseorang untuk mengangkat musuhnya sebagai pemimpinnya. Bila umat Islam mengangkat orangorang Kafir sebagai pemimpinnya, hal tersebut berarti umat Islam seolah memandang bahwa jalan yang ditempuh oleh orang-orang Kafir itu baik. Hal ini tidak boleh terjadi, sebab dengan meridhai kekafiran berarti seseorang telah Kafir. ${ }^{42}$

Seraya menyadur pendapat Thabathaba'i, H.M. Mujar Ibnu Syarif menegaskan bahwa mengangkat orang-orang kafir sebagai pemimpin umat Islam justru lebih berbahaya daripada kekafiran kaum kafir dan kemusyrikan kaum musyrik. Kaum kafir itu, lanjut Thabathaba'i, adalah musuh umat Islam, dan bila musuhitu telah diambil sebagai teman, maka kala itu ia telah berubah menjadi musuh dalam selimut yang jauh lebih sulit untuk dihadapi ketimbang musuh yang nyata-nyata berada di luar lingkungan umat Islam. Hal ini, tegas Thabathaba'i, tidak boleh terjadi, sebab bila tidak, maka umat Islam akan mengalami kehancuran. ${ }^{43}$

Prof. Hamka Dalam Tafsir al-Azhar menjelaskan, wajib bagi kita mengambil pemimpin dari orang muslim. Allah memberi peringatan dengan tegas bahwa memilih orang kafir menjadi pemimpin adalah perangai kelakuan orang munafik. Pada ayat ini ditegaskan kepada orang-orang beriman agar tidak mengambil orang kafir sebagai pemimpin. Ini dikarenakan mereka tidak percaya kepada tuhan, dan keingkaran mereka kepada tuhan dan peraturan-peraturan tuhan akan menyebabkan rencana kepemimpinan mereka tidak tentu arah. ${ }^{44}$

Abu Tholib Khalik mengutip bahwa, di kalangan umat Islam yang tergolong paling keras menolak presiden non-Muslim adalah Sayyid Qutb. Lebih dari itu ia bahkan berpendapat, sekedar menolong dan atau mengadakan perjanjian persahabatan dengan non-Muslim saja, utamanya dengan kaum Yahudi dan Nasrani, umat Muslim tidakdiperbolehkan melakukannya. Memilih pemimpin non Muslim berarti memberikan kepercayaan dan loyalitas, hal ini berbeda dengan toleransi (muamalah bi al-Hasan). Sayyid Qutub menolak dengan tegas paham yang bernuansa sekuler atheistik yang mendukung kerjasama dan saling menolong dengan ahli kitab. ${ }^{45}$

Sedangkan Ibnu Taimiyah berpendapat bahwa sistem merupakan hal penting, tetapi yang terpenting adalah seseorang yang menduduki jabatan kekuasaan harus memenuhi persyaratan, pertama, memperoleh dukungan mayoritas umat dalam Islam ditentukan dengan konsultasi dan bai'at. Kedua memenangkan dukungan dari kalangan Ahl asy-Syaukah ${ }^{46}$ atau unsur pemegang kekuasaan dalam masyarakat dan

${ }^{42}$ Az-Zamakhsyari, Al-Kasysyāf' 'an Haqā'iq at-Tanzīl wa 'Uyūn al-Aqāwil fi Wujūh at-Ta'wīl (Cet. II; Mesir: Syirkah Maktabah wa Mathba'ah Muștafaal-Bābi al-Ḥalabi wa Auladuh, 1392 H/1972 M), h. 422 .

${ }^{43}$ Mujar Ibn Syarif, "Memilih Presiden Non Muslim di Negara Muslim dalam Perspektif Hukum Islam", dalam Jurnal Konstitusi PPK Fakultas Syariah IAIN Antasari, Vol II nomer 1 Tahun 2009, h. 98.

${ }^{44}$ Hamka. Tafsir Al-azhar juz II (Singapura: Pustaka Nasional, 1999), h. 412.

${ }^{45}$ Abu Tholib Khalik, "Pemimpin Non Muslim dalam Persfektif Ibnu Taimiyah"dalam Jurna Analisis PPKFakultas Ushuluddin IAIN Raden Intan Lampung, Vol XIV nomor 1 Tahun 2014, h. 67.

${ }^{46} \mathrm{Ahl}$ asy-Syaukah adalah sekelompok orang yang berpengaruh dan menyatakan kesetiaan kepada imam yang diangkat, konsep Ahl al-Syaukah ditawarkan Ibn Taimiyah dalam rangka ketidaksetujuannya dengan lembaga Ahl al-Halli wa al-Aqdi yang ditawarkan al-Mawardi dan alBaqillani. 
ketiga, memiliki syarat kekuatan pribadi dan dapat dipercaya ${ }^{47}$ dengan sikap yang jujur, amanah, adil, maka seorang pemimpin akan mampu memberikan kemaslahatan bersama kepada rakyatnya.Atas dasar alasan semacam itu, maka sangat wajar jika kemudian Ibnu Taimiyah mengeluarkan statement yang sangat "berani", yakni "lebih baik dipimpin oleh pemimpin kafir yang adil, daripada dipimpin oleh pemimpin muslim yang dzalim". Sebab, orang yang dapat diangkat menjadi pemimpin adalah orangyang memiliki kekuatan dan integritas, ${ }^{48}$ mampu berbuat adil dan memiliki komitmen yang kuat terhadap kemakmuran rakyat yang ia pimpin terlepas dari latar belakang keimanannya.

Sebaliknya beberapa pemikir muslim "liberal" memberikan jawaban serta memposisikan diri berseberangan dengan ulama penentang pemimpin non muslim. Mereka antara lain: Mahmud Muhammad Thaha, Abdullah Ahmed al-Na'im, Thariq al-Bishri, Asghar Ali Enginer, Abdu al-Rahman al-Kawaqibi, Muhammad Said alAsmawi. Menurut al-Asmawi, sebagaimana dikutip Mujar, ayat larangan pemilih pemimpin non muslim adalah ayat Madaniyah yang bersifat temporer. Saat turun ayat tersebut, umat Islam sedang berperang. Ketika dalam sebuah negara tidak ada perang antara muslim dengan non muslim, maka ayat tersebut bisa tidak diterapkan. ${ }^{49}$

Al-Maududi menyatakan bahwa semua jabatan pemerintah-an terbuka bagi kaum dzimmi, kecuali sedikit jabatan kunci semisal kepala negara dan majelis permusyawaratan. Kaum Muslim tidak dibenarkan merampas hak-hak mereka selama tidak bertentangan dengan perintah syariat Islam. Dengan kata lain hanya orang Islamlah yang mempunyai hak untuk menduduki jabatan kepala negara dan majelis syura, karena jabatan tersebut akan menjadi penentu lahirnya kebijakan-kebijakan kunci dalam tatanan pemerintahan. ${ }^{50}$ Namun untuk posisi dan kedudukan lainnya, semisal badan administrasi negara, maka kaum minoritas non-Muslim berhak mendudukinya sesuai prosedur dan aturan dalam negara Islam tersebut..$^{51}$

\section{Fatwa tentang Memilih Pemimpin Non Muslim}

Terkait dengan memilih pemimpin non-Muslim NU melalui Bahtsul Masail mengeluarkan fatwa pada Muktamar NU XXX yang dilaksanakan di Lirboyo, Kediri, Jawa Timur pada tanggal 21-27 November 1999 tentang Hukum Memilih Pejabat dari Kalangan Non-Muslim adalah:

1. Pertanyaan: Bagaimana hukum orang Islam menguasakan urusan kenegaraan kepada orang non Islam?

2. Jawaban: Orang Islam tidak boleh menguasakan urusan kenegaraan kepada orang non-Islam, kecuali dalam keadaan dharurat, yaitu:

\footnotetext{
${ }^{47}$ Ahmad Sukardja, Fikih Siyasah, dalam Ensiklopedi Tematis Dunia Islam. (Cet. ke-4. Jakarta: PT. Ichtiar Baru Van Hoeve, 2002), h. 211. Baca juga, Mutawalli, "Aktualisai Maslahah dalam Politik Islam Persepektif Ibn Taimiyah". Makalah tidak diterbitkan, Mataram, 2012). h. 12.

${ }^{48}$ Taimiyah, Ibn. As-Siyāsah asy-Syar‘iyyah fi Iṣlāh ar-Rā‘i wa ar-Rā'iyyah. (Beirut: Dar alKutub al-Ilmiyah, tt), h. 22-23.

${ }^{49}$ Mujar Ibn Syarif, "Memilih Presiden Non Muslim di Negara Muslim dalam Perspektif Hukum Islam", dalam Jurnal Konstitusi PPK Fakultas Syariah IAIN Antasari, Vol II nomer 1 Tahun 2009, h. 103-105.

${ }^{50} \mathrm{Abu}$ al-A'la Maududi, Hak-hak Asasi Manusia dalam Islam. Terj. Bambang Iriana Djaja Atmadja (Jakarta: Bumi Aksara, 2005), h. 321.

${ }^{51}$ Rasyid Al-Ghanusyi, Huqūq al-Muwātanah: Huqūq Ghair al-Muslim fì al-Mujtama' alIslāmi(Virginia: Ma’had al-Alam Tial-Fikr al-Islāmi, 1993), h. 73.
} 
(1) Dalam bidang-bidang yang tidak bisa ditangani sendiri oleh orang Islam secara langsung atau tidak langsung karena factor kemampuan,

(2) Dalam bidang-bidang yang ada orang Islam berkemampuan untuk menangani, tetapi terdapat indikasi kuat bahwa yang bersangkutan khianat,

(3) Sepanjang penguasaan urusan kenegaraan kepada non-Islam itu nyata membawa manfaat. ${ }^{52}$

Sedangkan Muhammadiyah melalui Majelis Tarjih Muhammadiyah dalam sidangnya pada hari Jum'at, 12 Zulkaidah 1430 H / 30 Oktober 2009 seputar Memilih Partai Politik dan Calon Legislatif butir 3 memberikan syarat bahwa calon pemimpin yang harus dipilih adalah Islam, dengan mengutip al-Qur'an Surah al-Maidah/5 ayat $51 .{ }^{53}$

Sementera itu, MUI dalam Keputusan Ijtima' Ulama Komisi Fatwa Se-Indonesia Ketiga Tahun 2009 tentang Menggunakan Hak Pilih dalam Pemilihan Umum.

1. Pemilihan Umum dalam pandangan Islam adalah upaya untuk memilih pemimpin atau wakil yang memenuhi syarat-syarat ideal bagi terwujudnya cita-cita bersama sesuai dengan aspirasi umat dan kepentingan bangsa.

2. Memilih pemimpin dalam Islam adalah kewajiban untuk menegakkan imamah dan imarah dalam kehidupan bersama.

3. Imamah dan Imarah dalam Islam menghajatkan syarat-syarat sesuai dengan ketentuan agar terwujud kemaslahatan dalam masyarakat.

4. Memilih pemimpin yang beriman dan bertakwa, jujur (siddiq), terpercaya (amanah), aktif dan aspiratif (tabligh), mempunya kemampuan (fathonah), dan memperjuangkan kepentingan umat Islam hukumnya adalah wajib.

5. Memilih pemimpin yang tidak memenuhi syarat-syarat sebagaimana disebutkan dalam butir 4 (empat) atau tidak memilih sama sekali padahal ada calon yang memenuhi syarat hukumnya adalah haram. ${ }^{54}$

\section{Kesimpulan}

1. Dalam al-Quran beragam istilah yang diberikan untuk memaknai kata pemimpin diantaranya: Khalifah, imam, sulthan, malik, ulil amri, dan waly. Pengistilahan tersebut karena Allah swt membicarkan konteks dimana kepemimpinan tersebut diberlakukan. Selanjutnya dalam Islam, kepemimpinan merupakan hal fundamental, sehingga seorang pemimpin harus adil, amanah, bermusyawarah dan menegakkan amr al-maruf wa nahy mungkar.

2. Hukum memilih pemimpin non muslim diisyaratkan dalam al-Quran salah satunya dalam QS.al-Maidah/5: 51. Selanjutnya beberapa ulama mengatakan haram memilih pemimpin Non-Muslim. Ada beberapa ulama yang memberikan kelonggaran/moderat dengan memberikan syarat ketika dalam keadaan darurat maka dibolehkan. MUI, memberikan fatwanya bahwa memilih pemimpin Non-

\footnotetext{
${ }^{52}$ Salah Mahfud, Solusi Hukum Islam: Keputusan Muktamar, Munas dan Konbes NU 1926-2004 (Cet. III;Kudus:Khalista, 2007), h. 211.

${ }^{53}$ Armansyah, Fatwa Majelis Tarjih Muhammadiyah: Kepemimpinan. https://arsiparmansyah.wordpress.com/2016/10/12/fatwa-majelis-tarjih muhammadiyah-kepemimpinan/ di akses tanggal 31 Desember 2016.

54 Majelis Ulama Indonesia (MUI), Himpunan Fatwa MUI Sejak 1975 (Jakarta: Erlangga, 2011), h. 867.
} 
Muslim adalah hukumnya haram. Namun keterlibatan kaum kafir dzimmi dalam pemerintahan dibolehkan pada posisi yang strategis seperti pemimpin maupun majelis syura.

\section{DAFTAR PUSTAKA}

Abduh, Muhammad . dan Riḍā, Rasyīd. Tafsir al-Qur'an al-Hakim (Tafsir al-Manār), Beirut : Dār al-Mā'rifah, t.t.

Al-Ghanusyi, Rasyid. Huqūq al-Muwătanah: Huqūq Ghair al-Muslim fí al-Mujtama' al-Islāmi, Virginia: Ma’had al-Alam Tial-Fikr al-Islāmi, 1993.

Ali, Atabik.\& Mudlor, Ahmad Zuhdi. Kamus Kontemporer Arab Indonesia, Yogyakarta: Yayasan Ali Maksum, tt.

al-Ișfahāni, Ar-Rāghib. Mufradāt Alfāza al-Qur'ān, Dār al-Qalam Damaskus, 1412/1992. al-Jașșāṣ, Abu Bakar Ahmad Ibn Ali ar-Razi. Aḥkām al-Qur'ān, Kairo: Maktabah wa Mathba'ah Abd ar-Rahman Muhammad, t.t.

Al-Mawardi, Imam. al-Ahkam al-Sulthaniyyah: Hukum-Hukum Penyelenggaraan Negara dalam Syariat Islam, pent. Fadli Bahri, Jakarta: Darul Falah, 2007.

Al-Munawar, Said Agil Husin. Al-Qur'an Membangun Tradisi Kesalehan Hakiki, Jakarta: Ciputat Press, 2002.

al-Sha'rāwī, Muhammad Mutawally. Tafsīr al-Sha'rāwī, Vol 4, Kairo : Maṭābi' Akhbār al-Yaum, 1997.

al-Zamakhsyari, al-Kasysyâf 'An Haqâiqi Ghamâmi al-Tanzîl wa 'Uyûn al-Aqawîl fî Wujûh al-Ta'wîl, vol. 2, Riyadh: Maktabah 'Abikan, 1998.

Armansyah, Fatwa Majelis Tarjih Muhammadiyah: Kepemimpinan. https://arsiparmansyah.wordpress.com/2016/10/12/fatwa-majelis-tarjih muhammadiyah-kepemimpinan/ di akses tanggal 31 Desember 2016.

ar-Rāzī,Fakhruddīn. Tafsīr al-Kabīr, juz 7, jilid 3, Dār al-Fikr Beirut 1425/2005.

az-Zhuhaili, . Tafsir al-Manar Fi al-Aqidah wa Syar`iyah Wa al-Manhaj juz 3,

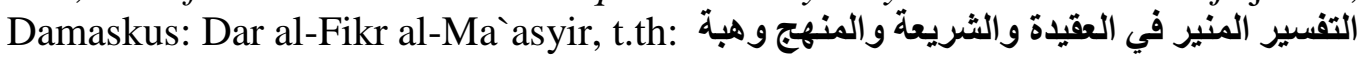
بن مصطفى الزحيلي الناشر : دار الفكر المعاصر - دمشق h. 198.

Hamka. Tafsir Al-azhar juz II, Singapura: Pustaka Nasional, 1999.

Ibn Arabi, Abu Bakr Muhammad ibn Abdillah. Aḥkām al-Qur'ān, Beirut: Dar alKutub al-'Ilmiyyah, 1988.

ibn Katshîr, Abu Fidâ al-. Tafsîr al-Qur'ân al- 'Azîm, Vol 1, Beirut: Dâr al-Fikr, 2011.

Ihsan, A. . "Referensi Pemikiran Politik NU", dalam Jurnal Refleksi: Jurnal Ilmu-ilmu Ushuluddin, vol. XI, No 2, 2009.

Ismail, Muhammad Ibrahim.Mu`jam al-Alfazh wa al-A`lam al-Qur`aniyat, al-Qahirat: Dar al-Fikr al-Arabi, t.th.

Kementerian Agama RI, al-Qur`an dan Terjemahnya, Jakarta: Syamil Qur`an, 2014. 
Sippah Chotban

Khalik, Abu Tholib."Pemimpin Non Muslim dalam Persfektif Ibnu Taimiyah"dalam Jurna Analisis PPKFakultas Ushuluddin IAIN Raden Intan Lampung, Vol XIV nomor 1 Tahun 2014.

Mahfud, Salah. Solusi Hukum Islam: Keputusan Muktamar, Munas dan Konbes NU 1926-2004, Kudus:Khalista, 2007.

Majelis Ulama Indonesia (MUI), Himpunan Fatwa MUI Sejak 1975, Jakarta: Erlangga, 2011.

Manzhur, Muhammad ibn. Lisanul I’rab, Juz 8Beirut: dar al-Shadir, 1968,: لسان العرب محمد بن مكرم بن منظور الأفريقي المصريدار صادر - بيروت

Maududi, Abu al-A'la. Hak-hak Asasi Manusia dalam Islam. Terj. Bambang Iriana Djaja Atmadja, Jakarta: Bumi Aksara, 2005.

Mohammad Said, Hakim. Moralitas politik: Konsep mengenai Negara, dalam A.E. Proyono (ed), Islam Pilihan Peradaban, Yogyakarta: Shalahuddin Press, 1884.

Mutawalli, “Aktualisai Maslahah dalam Politik Islam Persepektif Ibn Taimiyah". Makalah tidak diterbitkan, Mataram, 2012.

Raharjo, M. Dawam. Ensiklopedi Al-Qur'an: Tafsir Sosial Berdasarkan Konsep-konsep Kunci, Jakarta: Paramadina, 2002.

Rivai, Veithzal. Kiat Memimpin Abad ke-21, Jakarta: Raja Grafindo. 2004.

Salim, Abdul Muin. Fiqh SIyasah: Konsepsi Kekuasaan Politik dalam al-Qur`an Jakarta: Raja Grafindo Persada, 2002.

Sukardja, Ahmad. Fikih Siyasah, dalam Ensiklopedi Tematis Dunia Islam. , Jakarta: PT. Ichtiar Baru Van Hoeve, 2002.

Syarif, Mujar Ibn. "Memilih Presiden Non Muslim di Negara Muslim dalam Perspektif Hukum Islam", dalam Jurnal Konstitusi PPK Fakultas Syariah IAIN Antasari, Vol II nomer 1 Tahun 2009.

Taimiyah, Ibn. As-Siyāsah asy-Syar'iyyah fi Iṣlāh ar-Rā'‘ wa ar-Rā'iyyah. Beirut: Dar al-Kutub al-Ilmiyah, tt.

Yusuf Ali, Abdullah, The Holy Quran, Text, Translation and Comentary, Lahore: Muhammad Ashraf, 1938. 